\title{
Improving the Practice of Landscape Design Collaboration between University and Local Community: Case study in Matsudo, Japan
}

\author{
Mariia Ermilova, Mitsunari Terada, Ryosuke Shimoda, Isami Kinoshita \\ Environmental Science and Landscape Architecture Course, Graduate School of Horticulture, \\ Chiba University, Matsudo 271- 8510, Japan \\ gboka.me@gmail.com, himitsukeychi@gmail.com, r.shimoda@chiba-u.jp, isamikinoshita@faculty.chiba-u.jp \\ Tel. (+81) 08020883012
}

\begin{abstract}
This paper is based on the two years community-based participatory action research (CBPAR), focusing on Cross-Cultural Design Collaboration (CCDC) landscape design studio, held in Iwase Neighborhood Association area, Matsudo, Japan. We first briefly introduce the problems of Japanese local community and introduce the priorities of collaboration between university and community in Japan. Then, we introduce the Design and Build program, which was incorporated into the Chiba University CCDC studio in 2014. The authors suggest "Students live in the Neighborhood Association" model as an effective way to facilitate the collaborative programs between university and local community. We critically reflect on the process of CCDC landscape design studio held in Iwase, Matsudo city in 2017-2018. Based on that, we provide the recommendations for the implementation of interdisciplinary practical programs in Universities, so they can contribute to the quality of life of local communities utilizing the suggested model.
\end{abstract}

Keywords: community, landscape design, interdisciplinary research, community-based participatory action research

eISBN 2398-4287 @ 2018. The Authors. Published for AMER ABRA cE- Bs by e-International Publishing House, Ltd., U.K. Peer-review under responsibility of AMER (Association of Malaysian Environment-Behaviour Researchers). ABRA (Association of Behavioural Researchers on Asians) and cE-Bs (Centre for EnvironmentBehaviour Studies), Faculty of Architecture, Planning \& Surveying, Universiti Teknologi MARA, Malaysia. https://doi.org/10.21834/e-bpj.v3i9.1491

\subsection{Introduction}

The speed of models and policies development in the scientific community outpacing the introduction of measures to improve the sustainability of communities at the local level. Often, recommendations remain on paper in political agendas and scientific publications. In the global community of researchers, there is an emerging trend for the practical-oriented research that can adapt and implement the sustainability policies directly at the local level.

International team of the researchers in landscape ecology science stating that there is a need for action at the local landscape scale (Opdam et al., 2013). They suggest taking iterative and collaborative methods for development of solutions, already developed in the design and planning disciplines and social sciences to the landscape ecology science (Nassauer, 2012; Nassauer and Opdam, 2008, Duff et al, 2009;).

Indeed, the planning field strongly support the iterative and collaborative methods, for example participatory design and action research in the local community, where citizens co-produce the knowledge or co-create the design for their living environment (Sanoff, 2000; Hester, 2006; Hou and Kinoshita 2005; 2007; Winterbottom, 2011; De la Pena, 2017).

This research paper aims to critically reflect on the process and outcome of the Cross-Cultural Design Collaboration (CCDC) landscape design studio held in Iwase Neighborhood Association area of Matsudo city during 2017-2018 to further improve the landscape interdisciplinary science and practice for sustainability at the local level, considering "Students live in the Neighborhood Association" model as way to improve the practice.

Objectives to achieve accordingly were:

1. Review the situation of Japanese local community and the way university helps to improve its quality of life.

eISSN: 2398-4287 @ 2018. The Authors. Published for AMER ABRA cE-Bs by e-International Publishing House, Ltd., UK. This is an open access article under the CC BYNC-ND license (http://creativecommons.org/licenses/by-nc-nd/4.0/). Peer-review under responsibility of AMER (Association of Malaysian Environment-Behaviour Researchers), ABRA (Association of Behavioural Researchers on Asians) and cE-Bs (Centre for Environment-Behaviour Studies), Faculty of Architecture, Planning \& Surveying, Universiti Teknologi MARA, Malaysia. https://doi.org/10.21834/e-bpj.v3i9.1491 
2. Critically reflect on the process and outcomes of the Cross-Cultural Design Collaboration program in Chiba University, Japan in 2017-2018, with consideration of "Students live in the Neighborhood Association" model.

3. Make recommendations based on the CCDC landscape studio experience to improve the landscape interdisciplinary science and practice for sustainability at the local level.

\subsection{Literature Review}

\subsection{Local community in Japan}

Speaking about local community in Japan must be associated with Neighborhood Association (Jichikai, or Chonaikai) (Applbaum, 1996; Pekkanen et al., 2014). Neighborhood Association which function is to organize activity from everyday life support of citizens like garbage separation and collection, safety and cleaning of common space, to leisure like dance club and festival. Jichikai (Chonaikai) in most of cases has a spatial territory historically belonging to a small urban district or village, which become part of a city later. Jichikai is voluntary, self-governed organization gathering annual fee for the needs of management. Recently in Japan the number of people who want to join Neighborhood Association is declining for various reasons. In this paper we will focus on the area management-layer of the Neighborhood Association activities, since they directly related with the landscape. Neighborhood Association carry a number of functions of local area management. This usually includes the regular seasonal cleaning of the territory, shredding and weeding grass in summer. Neighborhood Association helps to regulate the issues between the citizens related to garbage utilization areas and general wellness like neat-looking neighborhood. Main areas of social work of the Neighborhood Associations across Japan are dictated by the socio-economic state of the Japanese society. Firstly, it is support of elderly population and adaptation to depopulation. Second, a disaster-preparation. It includes the training for the future disasters and straitening the social network. As said above, local communities formed by Neighborhood Association has declining members, especially among young generation. Thus, it has decreasing power for local change.

\subsection{University as a center of community program in Japan}

One of the best opportunities to act on the local scale can be provided by university-community partnerships (Reardon, 2006; Amey \& Brown, 2005) In Asia, there are programs for working with local communities in National Chi Nan University of Taiwan (Oliver Su, 2018). In 2013, the COC+ program "Center Of Community" was launched in Japan. It aims to develop Universities as the centers of regional regeneration and revitalization by encouraging universities to collaborate with local communities (MEXT, 2012; Horiuchi \& Takahashi, 2016). Graduate School of Horticulture of Chiba University define the area of research work as "Food and Greenery". The function of Chiba University from old times was providing skillful gardeners to keep gardens of wealthy people, who lived in the area near Tokyo and sustaining agricultural activity to provide the food. Few decades ago people from Matsudo area was privileged to buy various plants from University and preciously nurtured their gardens. Now the plants came available through supermarkets. What is the role of University for community now? There are research projects, which are made in local community, which Chiba University students have been doing in recent years. They can be united in the focus area of "green corridor", which connect Chiba University and central Matsudo city. One of the activities in "green corridor" is edible landscape project in Iwase Neighborhood Association, which allowed to locate the Cross-Cultural Design Collaboration (CCDC) studio and provided the opportunity to design and build on the landscape level for Iwase community.

\subsection{Design and Build program}

Daniel Winterbottom, the organizer of original Design and Build program in the University of Washington, who brought it to Chiba University in Japan in 2014 describe the essence of it as following: "Most academic design studios engage in hypothetical projects lacking direct community participation, feedback and engagement. Design-build (d/b) synthesizes skills taught elsewhere in the curriculum, including design, communication, and technical. Compared to typical studio-based formats, the $\mathrm{d} / \mathrm{b}$ model is significant in: it encourages rapid and iterative user-driven design, works with real world constraints, and considers construction methods and materials throughout the process. D/b projects embody the social, ecological and health priorities foundational to the profession" (Winterbottom, 2011).

However, he notices that managing professors must "dedicate time prior to and following the project to secure projects, plan with the community, secure resources and donations. ... since many of these projects are ...not embedded in the departmental curriculum." This indeed requires the element of sacrifice of time and effort for the project to have a positive outcome. That is why we suggest a model, where the burden of the project management is spread between the management team, formed partly by the graduate students, conducting research in the community (Figure 2). Design and Build program in Chiba university, incorporated into CCDC landscape design studio takes a week of active work with international students and teachers. However, the conceptual part of the project is a result of the two years of constant community design work within the Iwase neighborhood and the logical continuation of it. As it becomes clear from the above, this "shadow" part of the work, or pre-research, is very important. 


\subsection{Method}

\subsection{Action research}

Action research can be defined as an approach in which the action researcher and a citizen collaborate in the identification of the problem and in the development of a solution based on their collaborative investigation (Mclntyre, 2008). The basis of the action research method is an "action-reflection loop", or so-called Plan-Do-Check-Act (PDCA) cycle. The process of action research is usually illustrated with spiral, which is moving towards the problem that all interested parties (researchers) are trying to solve (Figure 1), (Hart, 1992). Participatory Action Research aims to solve the problem on the spot, adjusting the existing knowledge and developing the best solution based on the local situation. Specifically, Community-Based Participatory Action Research (CBPAR) emphasizing that community members take active role in the whole research process, from establishing the research question to reflection on the results, developing tools and analysis.

\section{Action Research Process}

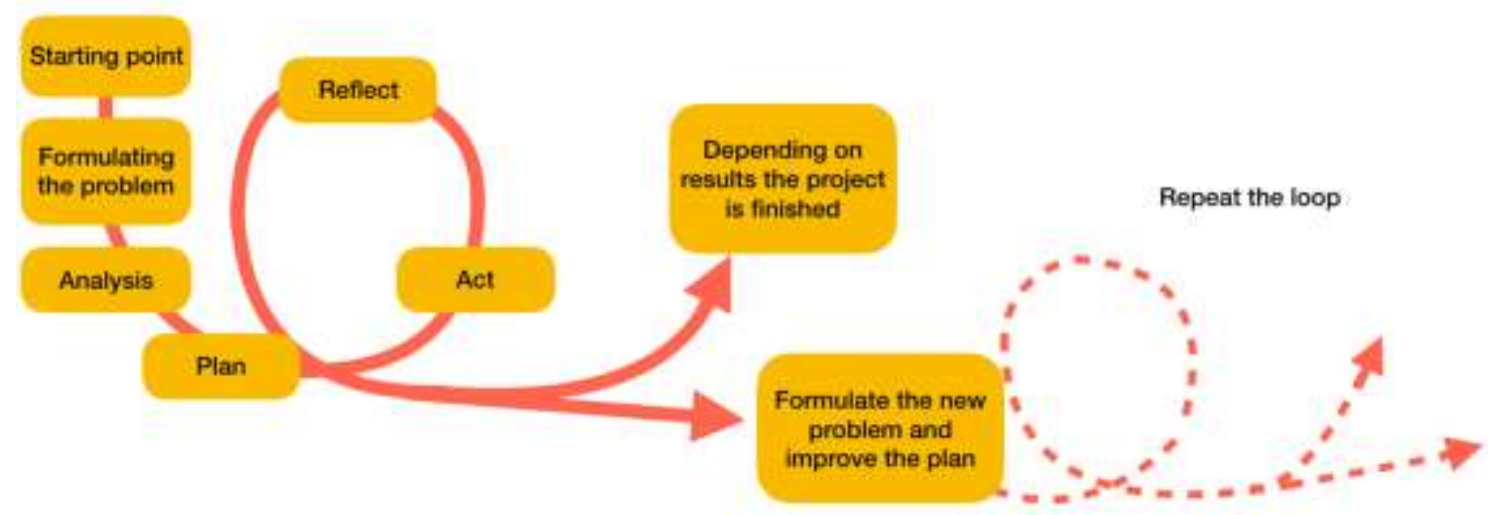

Figure 1. Drawn from the description of action research process in the book "Children's participation" (Hart, 1992) by the authors.

\section{2 "Students live in the Neighborhood Association" model}

Young specialists, as referred university students have a potential to facilitate communication between older people and younger generation. That can contribute to the Japanese local community, where due to social situation there is a gap between old and young generation. Young specialist or researcher's position allows him to have an outsider (neutral), advisory, proactive role in the community development and give it new directions.

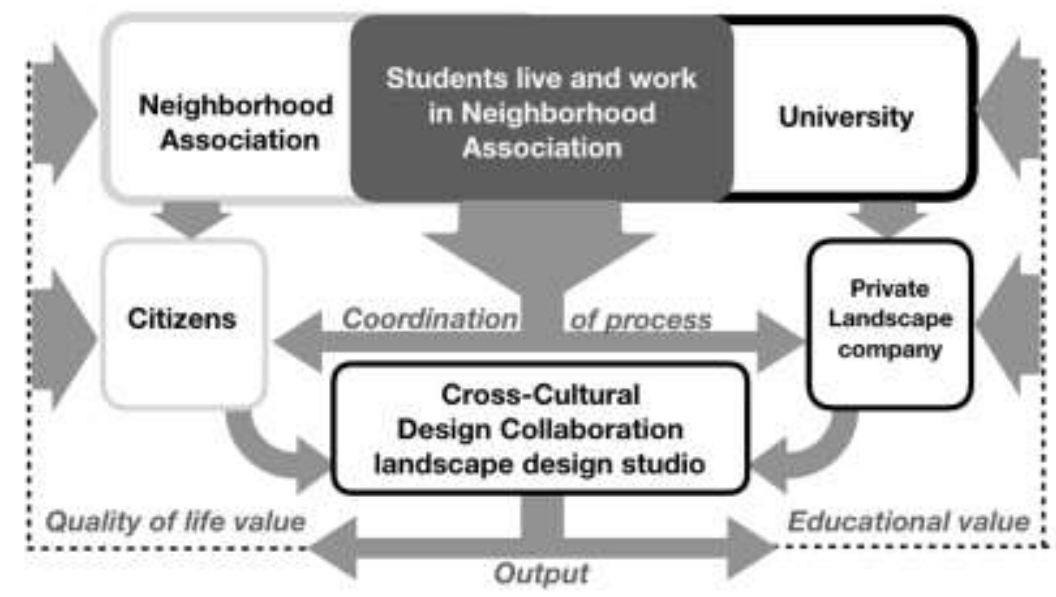

Figure 2. Cycle scheme of the CCDC landscape design studio collaboration in Iwase Neighborhood Association of Matsudo city, roles and value outputs for different stakeholders of the project.

The project in Iwase Neighborhood Association, was started by two students of Chiba University Graduate School of Horticulture in 2016 (Terada and Ermilova, 2017; Terada et al., 2018) with a name "Students live in the Neighborhood Association". While living in the building, belonging to Iwase Neighborhood Association for free, they conduct the projects and research activity, aiming to revitalize the community. This university-community collaboration showed itself effective for the practical landscape design program like CCDC studio (Figure 2), proving the outcomes for both students and local community. 


\subsection{Scope of the current research}

The main focus of this paper is on design development and implementation process, which was made during the CCDC design studio in August 2017 and 2018, by the group of international students in $2017(\mathrm{~N}=19)$ and $2018(\mathrm{~N}=35)$, as well as community stakeholders $(\mathrm{N}=11)$ and program managers $(\mathrm{N}=4)$.

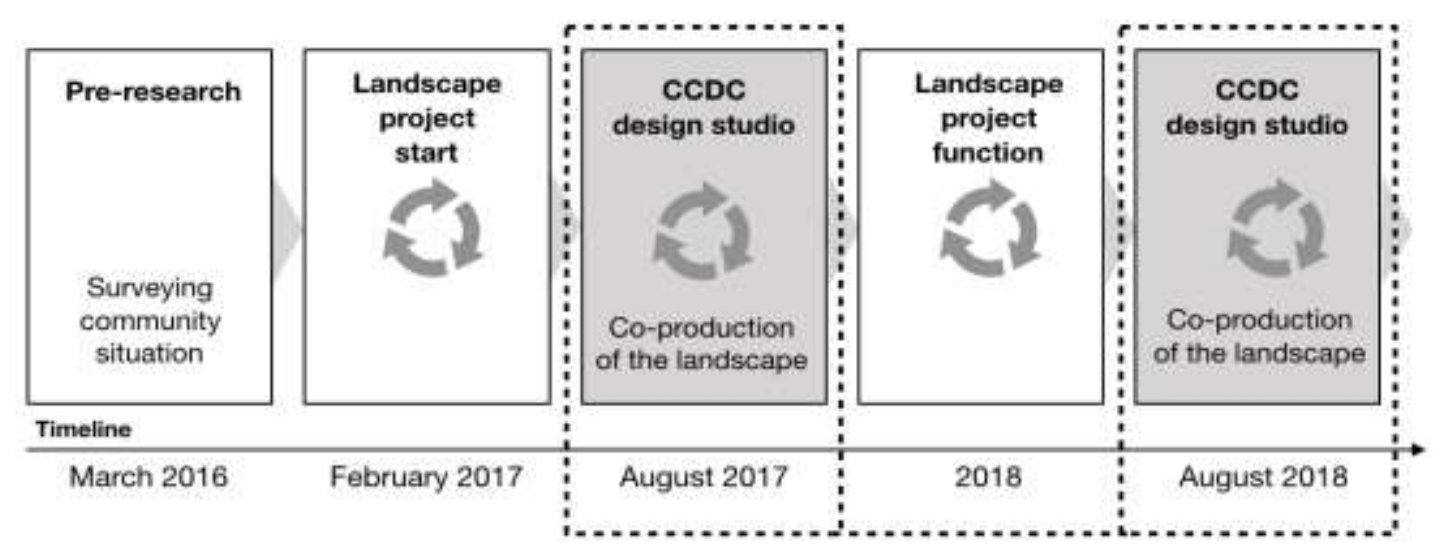

Figure 3. The Action Research done in Iwase community since March 2016 and the scope of current paper - action-reflection loop of practical coproduction of landscape in August 2017 and 2018 (frame made by the dashed line).

Through participatory mapping and hearing pre-research in 2016-2017 (Ermilova, 2017) (Figure 3) we realized, that area suffered in an urban development project, losing its natural environment. As a response to this, we suggested making a practical project on landscape design, which will create spaces to connect with nature on a daily basis. For that, we interviewed citizens, who agreed to participate in the collaboration. They requested to create the gardens from scratch, improve already existing community gardens, improve the image of the mountain slope landscape.

We divide the CCDC design studio into six stages (Figure 4): 1. Search for community collaborators 2 . Formulating the studio theme according to community request 3 . Design of proposals 4 . Check of proposals with local stakeholders 5. Proposals Implementation 6. Post-implementation evaluation.

(1)

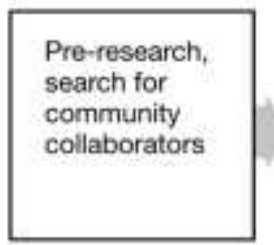

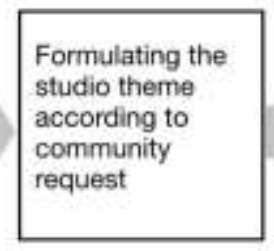

(3)

(4)

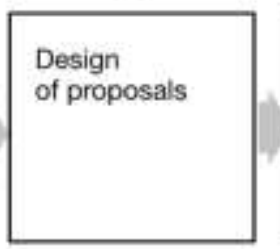

(5)

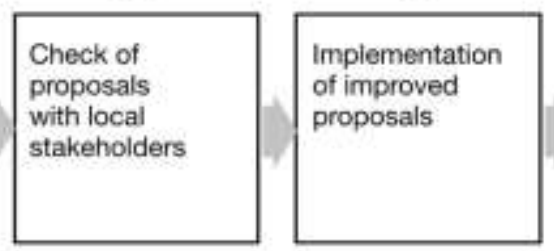

(6)

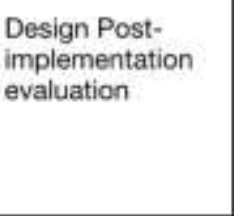

Figure 4. The scheme of the CCDC design studio six steps.

Data collection methods included participatory observation, video recording, semi-structured in-depth interviews, questionnaire, focus group discussions and literature review. We triangulated the research through using multiple data sources. The information was coded manually and classified using KJ method. The KJ Method is an approach to problem-solving and information sorting, developed by Japanese ethnologist Jiro Kawakita. This method puts unstructured information on a subject matter of interest into order through alternating divergent and convergent thinking steps (Scupin, 1997; Kunifuji, 2016).

\subsection{Location background}

Matsudo city was developed rapidly as a bed town to commute to Tokyo. Iwase community is a wealthy district, seven minutes' walk distance from the Matsudo station. The topography of the area is a valley, surrounded by the forested slopes. By the development into a bed town, mountain slopes in whole area were build up and the natural water balance in the terrestrial ecosystem was disturbed. From local people we get to know, that originally these mountain slopes provided the water springs to this area, and water was used on rice paddies, for washing, etc. Covered by the forest, slopes themselves provided plants, soil material and place for play. However, right now the land on the slopes is mostly belong to the private company and not available.

\subsection{Design and build program: Cross-Cultural Design Collaboration studio in Chiba University, Japan}

The CCDC studio is a summer program, hosted by Chiba University, collecting landscape architecture students from around the world to create practical design projects in an international environment. In two years, 2017-2018 we had 55 students from Japan, China, Switzerland, UK, Germany, Malaysia, Thailand, U.S.A., Russia, working in 3 teams at 3 locations each year. These two years the CCDC 
program was held at the Iwase district on the basis of the "Students Live in the Neighborhood Association" project, which provided the pre-research part (Terada \& Ermilova, 2017; Ermilova, 2017; Terada et al., 2018). The pre-research was conducted since March 2016. It included the participatory mapping $(\mathrm{N}=30)$, hearing $(\mathrm{N}=60)$ and non-formal interviews with local citizens.

In 2017, previous to the CCDC studio, we send the questions list to the agreed beforehand possible participating local people (private land owner, community garden leader, Neighborhood Association managers). They replied to our questions, from which we made a formal request to the design proposals from students.

In 2018, prior to CCDC studio, several interviews were conducted with the Neighborhood Association managers. Students-managers of Neighborhood Association together with the professors, assigned to the program, investigated the lands around the local community two times. Additionally, we visited potential participants from the local community (private land owners) with a trustee from the Neighborhood Association. Few meetings were made by the trustee himself, without students. After three meetings, one land owner gave his final consent on the use of his land as a project site.

Figure 5, 6, 7, 8, 9, are illustrating the process of the CCDC studio as it was developing in Iwase in August 2018.

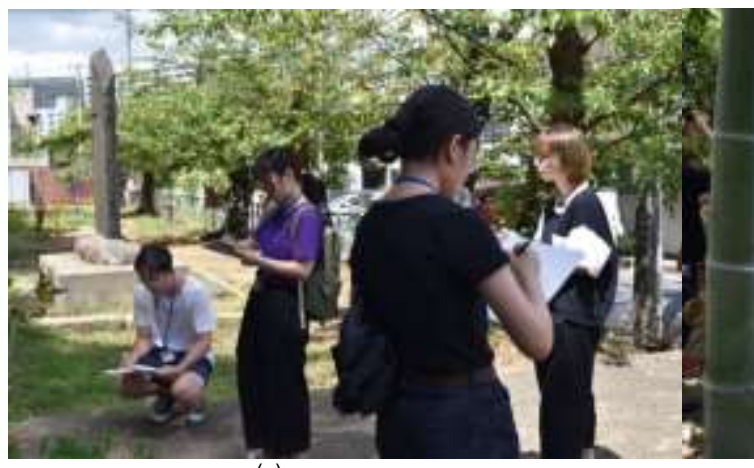

(a)

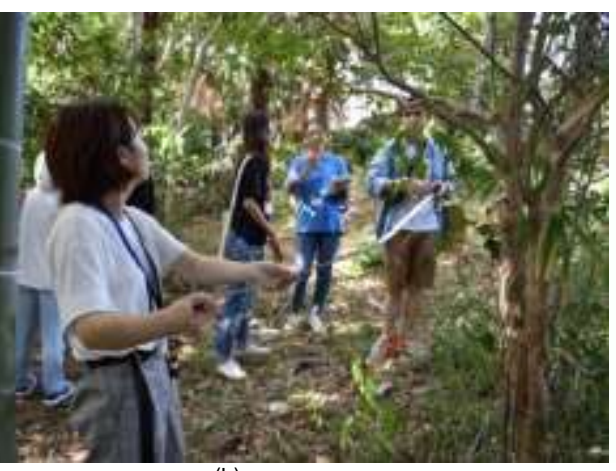

(b)

Figure 5. (a) Sketching on the site to get an image of the local landscape. (b) Measurements and cleaning on the site prior to design process (CCDC studio).

Photo by Mariia Ermilova, 2018.

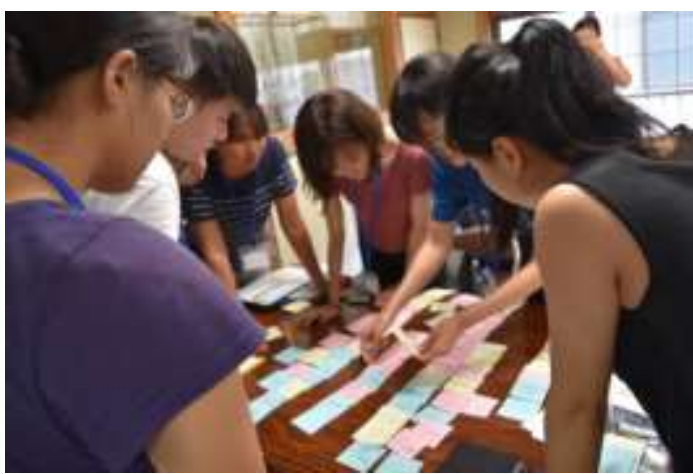

(a)

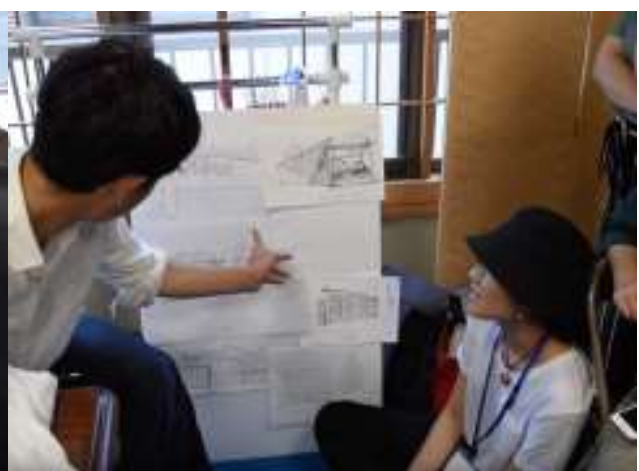

(b)

Figure 6. (a) Students organizing the brainstorm to decide the contents of their design proposal. (b) Communicating the design ideas with sketches, made on the site and developed into proposal (CCDC studio). Photo by Mariia Ermilova, 2018.

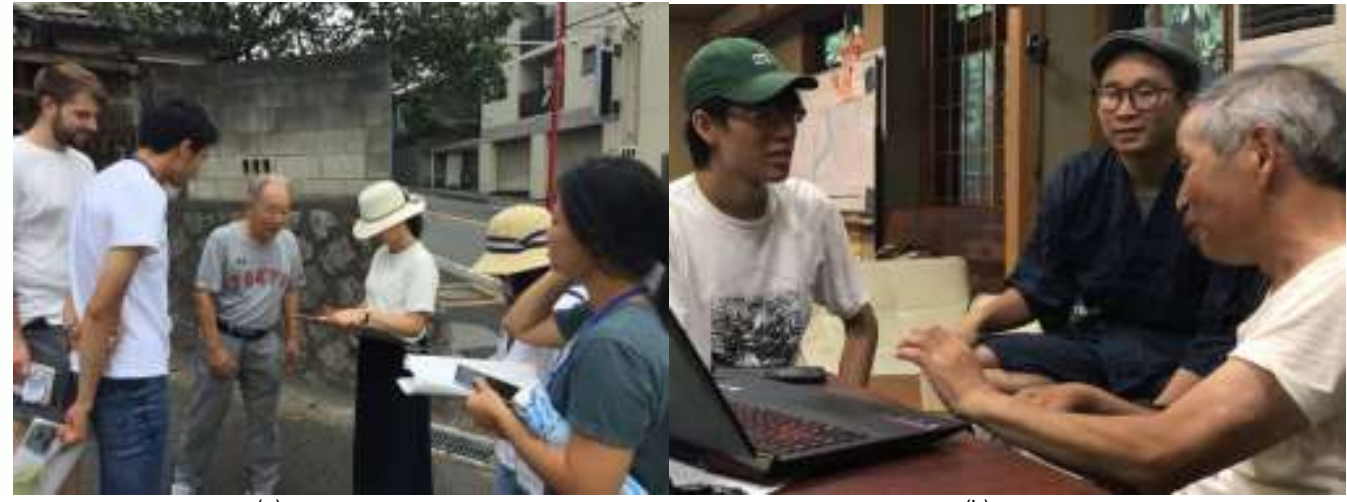

(a) (b)

Figure 7. (a) Students interviewing the local people of Iwase community during the CCDC studio 2018. (b) The student-participant, the student project manager and the landowner are confirming the design suggestion implementation plan in August 2018.

Photo by Mariia Ermilova, 2018. 


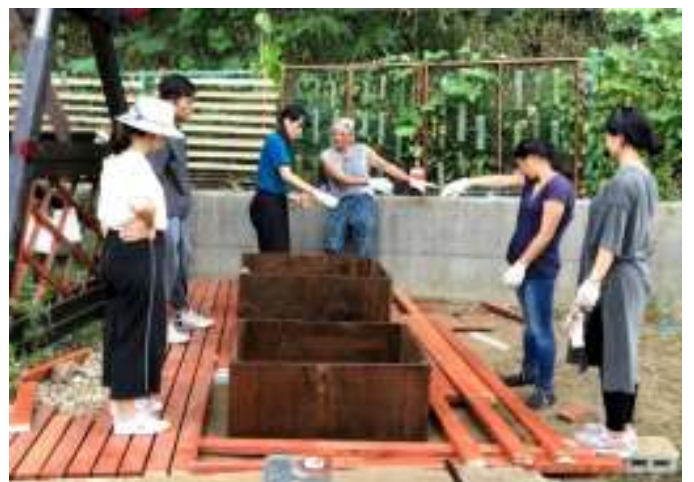

(a)

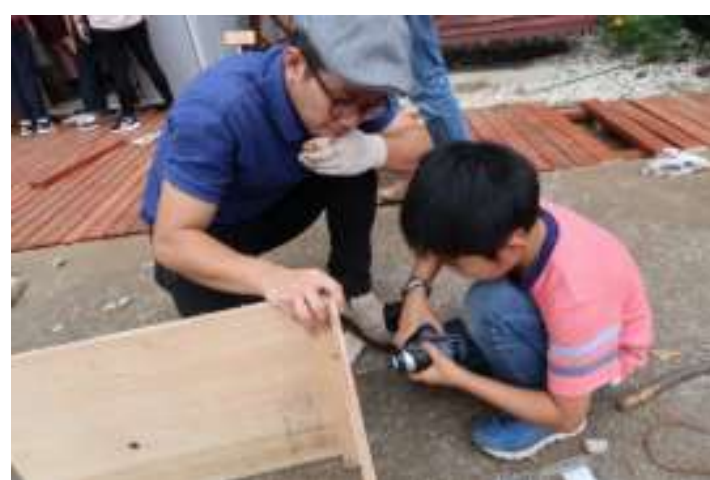

(b)

Figure 8. (a) Co-creating with local citizens is an important part of the process, ensuring the ownership of the process and responsibility for results, building together. (b) Children taking part in the process (CCDC studio). Photo by Mariia Ermilova, 2018.

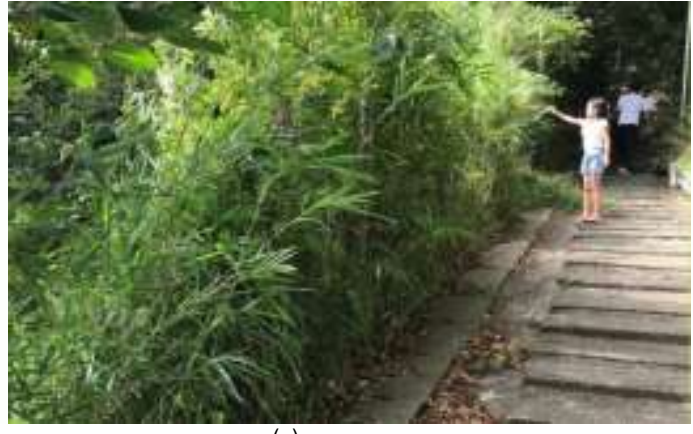

(a)

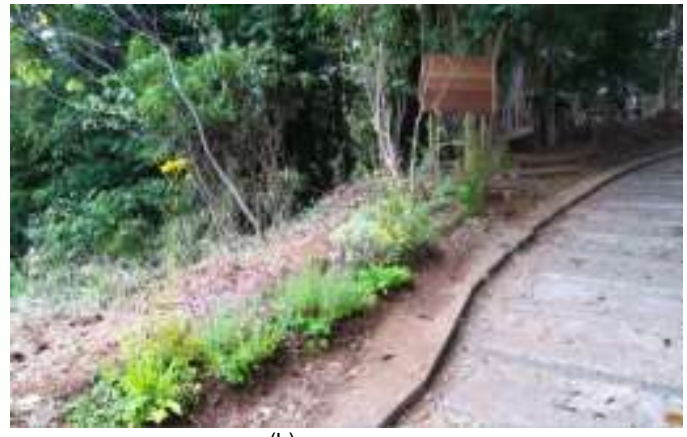

(b)

Figure 9. Mountain slope location before (a) and after (b) the CCDC design studio in 2018. Instead of the bamboo grass the wild native flowers are planted in a form of a "floral mat".

Photo by Mariia Ermilova and Mitsunari Terada, 2018.

\subsection{Results and Discussion}

\subsection{Practical results of the CCDC studio in year 2017-2018}

In year 2017, due to pre-research interviews we were able to negotiate for a private land development into community garden. "Floral mat," a landscape design material compound of native species of flowering perennial plants, brought the "nostalgic landscape" to the urban setting. The garden on the private land became a community garden and a place for learning about environment. Group of neighbors organized by the land owner formed a community of practice caring about the garden, learning the use of plants and observing the native flower bloom (refer to the full list of objects in Table 1).

Inspired by the success of 2017, the 2018-year studio was "linking landscape and people." It nicely describes the community design process. People connected with the landscape and each other through the process of co-creation. We hope it will lead to further flourishment of Iwase. During the CCDC in 2018 we negotiated with the mister S, owner of the forest on the slope, to help with the management and create design to share the wellness of the slope forest with other community members. The team assigned to community center create the wooden deck with square planters, the cover for the storage room and fence decorations, as well as Japanese-style rain garden with native plants. Some of the materials from the site were recycled. The second team worked on the mountain slope and developed it from the nature landscaping perspective. They clean the forest and reused the materials, appeared as a result of "cleaning": bamboo, concrete polls, wood. The third team worked from the planning perspective and create the map and the route, introducing Iwase. They walked around the community and interviewed citizens, as well observed it while sketching. All locations were developed with concepts, based on the local people's requests, received while interview and various hearings, held during the two years (Table 1).

\subsection{Reflective results}

After finishing the project, we send the evaluation questionnaire to all participants. They were satisfied with the location and assistance, especially they valued the practical character of our work. Students appreciated cultural experiences - Bon Odori festival and visits to the house of local people, as well as welcoming and closing party in the community center. Local people also expressed their appreciation of communication with foreign students and Chiba university students and teachers. As a result of the qualitative 
analysis of the interviews with local citizens and students' responses on questionnaire, as well as project managers reflection, following 3 main topics appeared: 1. Management 2. Cross-cultural awareness 3 . Materials and other support.

\subsubsection{Management \\ Local coordinator}

Local coordinator, mediator person, who is constantly keeping in touch with the community members, play a crucial role in the organizing of smooth process. You need to provide students with the creative work, but at the same time to ensure that they make something what community really need and will use. This is the contradiction which need to be balanced. Here comes the necessity to have some connectors, who collect much of the information, at the same time being trustworthy enough to collaborate from the point of view of local people. In our case, this role was performed by the students, living in the Neighborhood Association.

\section{Realistic abilities assessment}

Students participate in the program with various goals, but as they need to get credits for graduation, they take this class. Even they understand the practical character of the program, the level of consciousness of each student is different, so it is necessary to deliver the level of responsibility in this project. In 2017, one team created the ambitious design and could not finish their object on time. Local person, who was the owner of the space was disturbed by it.

\section{Sharing the responsibility}

The owner of the land was irritated with the irresponsibility of students and demanded the immediate completion of the entire plan, which was not finished by the end of project. However, during the summer holidays students go home and are physically unable to do that. As a result, the completion of objects was postponed to one and a half months, which led to displeasure and criticism from the owner. In this case, it should be noted that the probability of such outcomes must be discussed with the owners or managers of the territories used in the project in order to avoid further disagreements. Local residents should understand the limited level of responsibility of students and should not demand the impossible, as well as actively take responsibility for the process and performance of the result by themselves, without waiting for "service". This mutual understanding and support will ensure the pleasure of working and reaching the goal together.

Table 1. The list of locations, tasks and completed objects of CCDC project in Iwase Neighborhood Association district of Matsudo city in 2017 - 2018

\begin{tabular}{|c|c|c|c|c|c|c|}
\hline 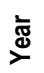 & $\begin{array}{c}\text { Team } \\
\text { (location) }\end{array}$ & Site photo & Problem & Task & Design suggestion & $\begin{array}{l}\text { Completed } \\
\text { object }\end{array}$ \\
\hline \multirow{3}{*}{ స్ } & $\begin{array}{l}\text { 1.Community } \\
\text { center }\end{array}$ & 1. & $\begin{array}{l}\text { The garden is difficult to } \\
\text { manage, there is no appeal, } \\
\text { homogenic landscape with } \\
\text { weeds, almost no flowers } \\
\text { for the pollinators. } \\
\text { There is aquarium, but it } \\
\text { suffers from heat and water } \\
\text { pollution. }\end{array}$ & $\begin{array}{l}\text { Biophilic design, } \\
\text { landscaping. Improve } \\
\text { the environment for } \\
\text { the urban wildlife } \\
\text { (pollinators). }\end{array}$ & $\begin{array}{l}\text { Japanese-style rain } \\
\text { garden with native } \\
\text { flowers, seedbank, } \\
\text { aquaponics based } \\
\text { on aquarium to } \\
\text { clean the water. }\end{array}$ & $\begin{array}{l}\text { Japanese-style } \\
\text { rain garden with } \\
\text { native flowers in } \\
\text { "floral mat", } \\
\text { aquaponics } \\
\text { systems with fish. }\end{array}$ \\
\hline & $\begin{array}{l}\text { 2.Community } \\
\text { herb garden } \\
\text { (private land) }\end{array}$ & & $\begin{array}{l}\text { Loneliness and declining } \\
\text { health of aging population } \\
\text { need for outside exercise, } \\
\text { nature therapy and } \\
\text { socialization. }\end{array}$ & $\begin{array}{l}\text { Create the garden with } \\
\text { herbs for five senses. }\end{array}$ & $\begin{array}{l}\text { Garden with } \\
\text { aromatic herbs, } \\
\text { edibles and native } \\
\text { flowers in "floral } \\
\text { mat". }\end{array}$ & $\begin{array}{l}\text { Community herb } \\
\text { garden for } \\
\text { elderly's health. }\end{array}$ \\
\hline & $\begin{array}{l}\text { 3.Community } \\
\text { garden } \\
\text { "Minnano } \\
\text { niwa" }\end{array}$ & & $\begin{array}{l}\text { Extinct of the urban bees, } \\
\text { slope erosion, need for the } \\
\text { better soil in the garden. }\end{array}$ & $\begin{array}{l}\text { Biophilic design, } \\
\text { landscaping. Improve } \\
\text { the environment for } \\
\text { the urban wildlife. }\end{array}$ & $\begin{array}{l}\text { "Floral mat" to stop } \\
\text { erosion on the } \\
\text { slopes, insect hotel } \\
\text { for the bees, } \\
\text { composter. }\end{array}$ & $\begin{array}{l}\text { Improved } \\
\text { "Minnanoniwa" } \\
\text { garden with the } \\
\text { new landmark - } \\
\text { insect hotel. }\end{array}$ \\
\hline 正 & $\begin{array}{l}4 . \\
\text { Community } \\
\text { center }\end{array}$ & $\underline{\bar{Z}}$ & $\begin{array}{l}\text { There is no integrity } \\
\text { between the objects in the } \\
\text { yard, image do not meet } \\
\text { the request of biophilia. } \\
\text { In the little garden there are } \\
\text { no flowers and it is difficult } \\
\text { to manage weeds. }\end{array}$ & $\begin{array}{l}\text { Biophilic design, } \\
\text { landscaping, united } \\
\text { image, open space to } \\
\text { enjoy the gardens. } \\
\text { In little garden create } \\
\text { the easy management } \\
\text { system, use the } \\
\text { rainwater, introduce } \\
\text { flowers for pollinators. }\end{array}$ & $\begin{array}{l}\text { Bamboo, wooden } \\
\text { planter for the herbs } \\
\text { display, wooden } \\
\text { deck for public open } \\
\text { space. } \\
\text { In little garden - } \\
\text { protection sheet and } \\
\text { native flowers mat, } \\
\text { rainwater collector, } \\
\text { mini-pond. }\end{array}$ & $\begin{array}{l}\text { Wooden deck, } \\
\text { planters, } \\
\text { decorative } \\
\text { biophilic-designed } \\
\text { fence, Japanese- } \\
\text { style raingarden } \\
\text { with "floral mat" } \\
\text { and rainwater } \\
\text { collector. }\end{array}$ \\
\hline
\end{tabular}




\begin{tabular}{|c|c|c|c|c|c|}
\hline $\begin{array}{l}\text { 5.Mountain } \\
\text { slope } \\
\text { (private land) }\end{array}$ & s. & $\begin{array}{l}\text { Nature here doesn't bring } \\
\text { friendly image due to little } \\
\text { management. On the night } \\
\text { time, it is gloomy dark. The } \\
\text { fence is old. Pervert } \\
\text { appeared here. There is } \\
\text { garbage around the place. }\end{array}$ & $\begin{array}{l}\text { Design to share the } \\
\text { wellness of the slope } \\
\text { forest with community } \\
\text { members. }\end{array}$ & $\begin{array}{l}\text { Eliminating design, } \\
\text { use of materials } \\
\text { from the site, } \\
\text { playground, bamboo } \\
\text { lanterns, "floral } \\
\text { mat". }\end{array}$ & $\begin{array}{l}\text { Playground with } \\
\text { objects from the } \\
\text { bamboo, clean } \\
\text { forest with the } \\
\text { view on } \\
\text { community, } \\
\text { lanterns, } \\
\text { information } \\
\text { desks. }\end{array}$ \\
\hline $\begin{array}{l}6 . \\
\text { Community } \\
\text { district area } \\
\text { (mapping) }\end{array}$ & ${ }_{1}$ & $\begin{array}{l}\text { There is no route or plan } \\
\text { which connect visually the } \\
\text { gardens and green zones } \\
\text { of community, presents its } \\
\text { landmarks. }\end{array}$ & $\begin{array}{l}\text { Create the map and } \\
\text { the route to introduce } \\
\text { the green areas of } \\
\text { Iwase for community. }\end{array}$ & $\begin{array}{l}\text { Map with the local } \\
\text { landmarks, } \\
\text { business, gardens } \\
\text { and plant species. }\end{array}$ & $\begin{array}{l}\text { Desk with the } \\
\text { hand-drawn map } \\
\text { in the front } \\
\text { garden of } \\
\text { community } \\
\text { center. }\end{array}$ \\
\hline
\end{tabular}

\subsubsection{Cross-Cultural awareness}

Cultural studies say, that communication with person of different culture is more difficult, than speaking other language. In the process of work students noticed the cultural difference, but even being aware of such sometimes does not help to act accordingly to smoothen the process. The most striking difference was seen between the European and Asian groups in general. Self-confident, speaking up European students easily took the leadership in the mixed groups with Asian students, but as a result this teams tended to make some mistakes, based on the overestimation of their power. Asian team members follow the leader and negotiate reservedly. This approach takes time, but as a result prove itself reasonable in the planning field. Cross-cultural awareness is necessary to avoid the conflicts and misunderstandings during the work. It is nice to raise the awareness of local customs during the program.

\section{"Hō-Ren-Sō" spinach rule of decision-making}

"Hō-Ren-Sō" is a business mantra or mnemonic acronym in Japanese business culture. It is an "abbreviation of "Hōkoku" (to report), "Renraku" (to inform) and "Sōdan" (to consult), and is more memorable as a homonym of hōrensō, the Japanese word for "spinach". It is utilized as a basic business rule in Japan to conduct smooth business communication. According to it, all decisions are proceeding slowly, including the negotiation with all interested parties, but at the same time ensures the ownership of the process by all participants and decrease the possibility for the mistake.

\subsubsection{Materials and other support \\ Receiving materials and support from the community}

Here, again, the local connection is getting essential. In order to create the Japanese stone garden and decorate the pond we needed a few big stones. The market price of these stones can start from 300 USD and is not affordable for student design project. However, as there are many empty houses in Japan, and they contain Japanese gardens with the stones, there is possibility to receive the materials from someone who do not need them. But it is only possible if you are in friendly relationship with the owner. In the same way we were able to receive the wood material from the local carpenter.

\section{Receiving materials and support from the landscape company}

During both CCDC studios in Iwase in both 2017 and 2018, we received the generous support from Nakada Nursery Ltd. - a company producing the Japanese native plants made "floral mats" for landscape design. The director, Mr. Nakada himself gave the lecture about his product. Using the floral mat in the design contribute to various dimensions of sustainability. Firstly, it is enhancing the native biodiversity. Flowers in the mat attract pollinators and support ecosystem as a whole. Second, it is reducing the carbon emissions, because native plants need less input for the management. Also, flowers attract the attention of citizens and connect them to Japanese culture.

\section{Foraging materials from the site}

Reusing materials from the site into design also helps to reduce the amount of garbage to be disposed. In Japan, garbage disposal has a high price, so it can be a reasonable solution to reduce the budget of the project. While working on the mountain slope site in 2018 students actively foraged the materials for all teams. They cut the bamboo and make fences, benches, lanterns, etc. Moreover, they reused the concrete piles from the fence into a "ladder" on the ground.

\subsection{Recommendation}

To organize an effective collaborative design and build landscape program in the local community we would recommend the following:

1. In order to design the program which will respond to the real needs of community members careful pre-research is needed.

2. To be able to make high-quality pre-research, it is better to organize a group of students-coordinators who will constantly live in the community and take a role of a mediator person ('Students live in Neighborhood Association" model), who is constantly keeping in touch with the community members. This person provides the background, pre-research and ensure that the program respond to the needs of the community. This mediator will also provide information about resources and opportunities from local people.

3. As much as possible involve local people in the process of co-production, to share the responsibility and avoid "customer" attitude. 
4. Rise the cross-cultural and local custom awareness among the participants, in order to maintain the peace in the community and among the program members.

\subsection{Conclusion}

We analyzed the process and outcome of the Cross-Cultural Design Collaboration (CCDC) landscape design studio held in Iwase community, Matsudo, during 2017-2018, utilizing the model "Students live in Neighborhood Association". From that, we draw the recommendations. We hope the reflection on this practical research in the local community can encourage other universities to act together with citizens toward sustainability on the local level, improving landscapes, affecting quality of life.

\section{Acknowledgement}

We would like to express our gratitude to Iwase Jichikai (Neighborhood Association), the land owners and all local collaborators. Special thanks to Nakada Nursery Ltd. for supporting this project with the lecture about native biodiversity in landscaping and "floral mat" material.

\section{Reference}

Amey, M. J., \& Brown, D. F. (2005). Interdisciplinary collaboration and academic work: A case study of a university-community partnership. New Directions for Teaching and Learning, 2005(102), 23-35. https://doi.org/10.1002/tt.194

Applbaum, K. (1996). The Endurance of Neighborhood Associations in a Japanese Commuter City. Urban Anthropology, 25(1).

De la Pena D. et al. (2017). Design as Democracy: Techniques for Collective Creativity. Island: Washington, DC.

Duff G, Garnett D, Jacklyn P, Landsberg J, Ludwig J, Morrison J, Novelly P, Walker D, Whitehead P. (2009). A collaborative design to adaptively manage for landscape sustainability in north Australia: lessons from a decade of cooperative research. Landscape Ecol 24 pp: 1135-1143

Ermilova, M. E. (2017). [Participatory mapping in Iwase Neighborhood Association using method of Gulliver Map]. Unpublished data.

Hart, R. (1992). Children's participation: From tokenism to citizenship. Earthscan/UNICEF International Child Development Centre, Florence.

Hester, R. T. (2006). Design for ecological democracy. Cambridge, Mass: MIT Press.

Horiuchi, S., \& Takahashi, T. (2016). Globalization, and regional revitalization in a local university of Japan. In B. Gonzalez (Ed.), Globalization: Economic, Political and Social issues (pp. 149-159). New York: Nova Science Publishers, Inc.

Hou, J. Kinoshita I. (2007). Bridging Community Differences through Informal Processes: Reexamining Participatory Planning in Seattle and Matsudo. Journal of Planning Education and Research Vol 26, Issue 3, pp. 301 - 314 . https://doi.org/10.1177/0739456X06297858

Hou, J., Kinoshita I., Ono S. (2005) Design Collaboration in the Space of Cross-Cultural Flows. Landscape Journal. vol. 24 no. 2 pp.125-139 https://doi.org/10.3368/li.24.2.125

Kunifuji S. (2016). A Japanese Problem-Solving Approach: The KJ Ho Method. In: Skulimowski A., Kacprzyk J. (eds) Knowledge, Information and Creativity Support Systems: Recent Trends, Advances and Solutions. Advances in Intelligent Systems and Computing, vol 364. Springer, Cham

Mclntyre A. (2008). Participatory action research. Sage Publications. pp: 79

Ministry of Education, Culture, Sports, Science and Technology (MEXT). (2012). Ji (chi) no kyoten daigaku ni yoru chihō sōsei suishin jigyō (COC +). (Program of the regional revitalization by the use of university as a knowledge base of community). http://www.mext.go.jp/a_menu/koutou/kaikaku/cocl

Nassauer, J. (2012). Landscape as medium and method for synthesis in urban ecological design. Landscape and Urban Planning.106 (3) pp: $221-229$

Oliver Su, Y., Chen, K., Tsai, Y., Su, H. (2018). How universities can work together with local communities to create a green, sustainable future. E3S Web of Conferences vol: 48

Opdam, P., Nassauer J., Wang Z., Albert C., Bentrup G., et. al. (2013) Science for action at the local landscape scale. Landscape Ecology. vol: 28 (8) pp: 1439-1445 https://doi.org/10.1007/s10980-013-9925-6

Pekkanen, R. J., Tsujinaka, Y., Yamamoto, H., Tsujinaka, Y., Yamamoto, H. (2014). Neighborhood Associations and Local Governance in Japan. Routledge. https://doi.org/10.4324/9781315797731

Reason, P., Bradbury, H. (2001). Handbook of action research: participative inquiry and practice. SAGE pp: 468

Sanoff, H. (2000). Community Participation Methods in Design and Planning. New York, NY: John Wiley and Sons, Inc

Scupin, R. (1997). The KJ Method: A Technique for Analyzing Data Derived from Japanese Ethnology. Human Organization, 56(2), 233-237. Retrieved from http://www.jstor.org/stable/44126786

Statistical Bureau of Japan. (2017). Statistical Handbook of Japan. Retrieved from http://www.stat.go.jp/english/data/handbook/index.html 
Terada M., Ermilova M., Tanaka R., Tomita F. (2018, June). Daigakusei, jichikai-kan ni sumu - Yuruyakana chiiki kankei no sai kōchiku kara chiiki no kyōiku kinō no saikō suru (Students live in Neighborhood Association: reconsidering the educational function of the community by the reconstruction of weak connections). Japan Architectural Institute, Children Support Council Meeting.

Terada M., Ermilova M. (2017, March). Daigakusei, jichikai-kan ni sumu - Kodomo mo sankaku dekiru machi-dzukuri no jissen. (Students live in Neighborhood Association: practical implementation of the planning with children participation). Children's Environment Association Kanto branch, Otsuma Women's University.

Winterbottom, D. (2011). Effecting Change Through Humanitarian Design, Service - Learning in Design and Planning. New Village Press. 